\title{
Sustainability of Off-Grid Photovoltaic Systems for Rural Electrification in Developing Countries: A Review
}

\author{
Sarah Feron ${ }^{1,2}$ \\ 1 Departamento de Física Universidad de Santiago de Chile, Ave. Bernardo O'Higgins 3363, \\ 9170022 Santiago, Chile; sarah.feron@usach.cl or sarah.feron@stud.leuphana.de \\ 2 Institute for Sustainability Governance, Leuphana University Lüneburg, Scharnhorststraße 1, \\ 21335 Lüneburg, Germany
}

Academic Editor: Helmut Haberl

Received: 19 September 2016; Accepted: 8 December 2016; Published: 19 December 2016

\begin{abstract}
A review on rural electrification programs and projects based on off-grid Photovoltaic (PV) systems, including Solar Pico Systems (SPS) and Solar Home Systems (SHS) in Developing Countries (DCs) was conducted. The goal was to highlight the main multidimensional drawbacks that may constrain the sustainability of these systems. Four dimensions of sustainability (institutional, economic, environmental and socio-cultural) were considered in this review. It was found that institutional flaws (such as the scarcity of durability/stability and enforcement of formal institutions, weak regulations or standards, incomplete decentralization/participation and the lack of institutional adaptability) seriously compromise the sustainability of rural electrification efforts in DCs. While the lack of an effective focalized subsidy scheme (e.g., cross-tariff scheme) for the electricity tariffs of the poor population often made projects economically unsustainable, the scarcity of environmental awareness, regulations or incentives has often turned presumably clean energy technologies into environmentally unsustainable projects. Progress regarding social acceptance, accuracy and cultural justice is urgently needed for ensuring the socio-cultural sustainability of rural electrification efforts in DCs. This review may help stakeholders to identify and (based on prior experiences) address the most severe drawbacks affecting the sustainability of rural electrification efforts in DCs.
\end{abstract}

Keywords: off-grid PV systems; rural electrification; developing countries; sustainable energy

\section{Introduction}

Access to energy offers great benefits to development through the provision of reliable and efficient lighting, heating, cooking, mechanical power, transport and telecommunication services [1,2]. Additionally, access to power has proven economic welfare, as productivity increases with businesses, substituting manual work by automated processes and finally leading to a positive virtuous growth cycle [3]. According to the United Nations (UN), Sustainable Development (SD) is not possible without sustainable energy, such that the issue has been prioritized by devoting a stand-alone SD goal (No. 7) to sustainable energy, which implies universal access to affordable, reliable and modern energy [4].

Although there is no universal definition of energy access and data are often scarce, the International Energy Agency (IEA) defines energy access as "household having access to electricity and to a relatively clean, safe means of cooking" [5]. For electricity, the methodology used by the IEA is fixing a minimum annual household consumption of 250 Kilowatt-hours $(\mathrm{kWh})$ in rural areas and $500 \mathrm{kWh}$ in urban areas [5]. According to this definition, 1.2 billion people worldwide are still lacking access to electricity, especially those from rural areas [6].

Though it is not the only alternative (see Figure 1), a viable solution for meeting the Seventh SD goal of the UN in vast rural areas still not served by the power grid is the deployment of renewable 
off-grid technology. One of these off-grid technologies is photovoltaic (PV) systems, which have been installed in many Developing Countries (DCs) aiming to provide people with electricity who would otherwise have to wait for years to get connected to the national power grid.

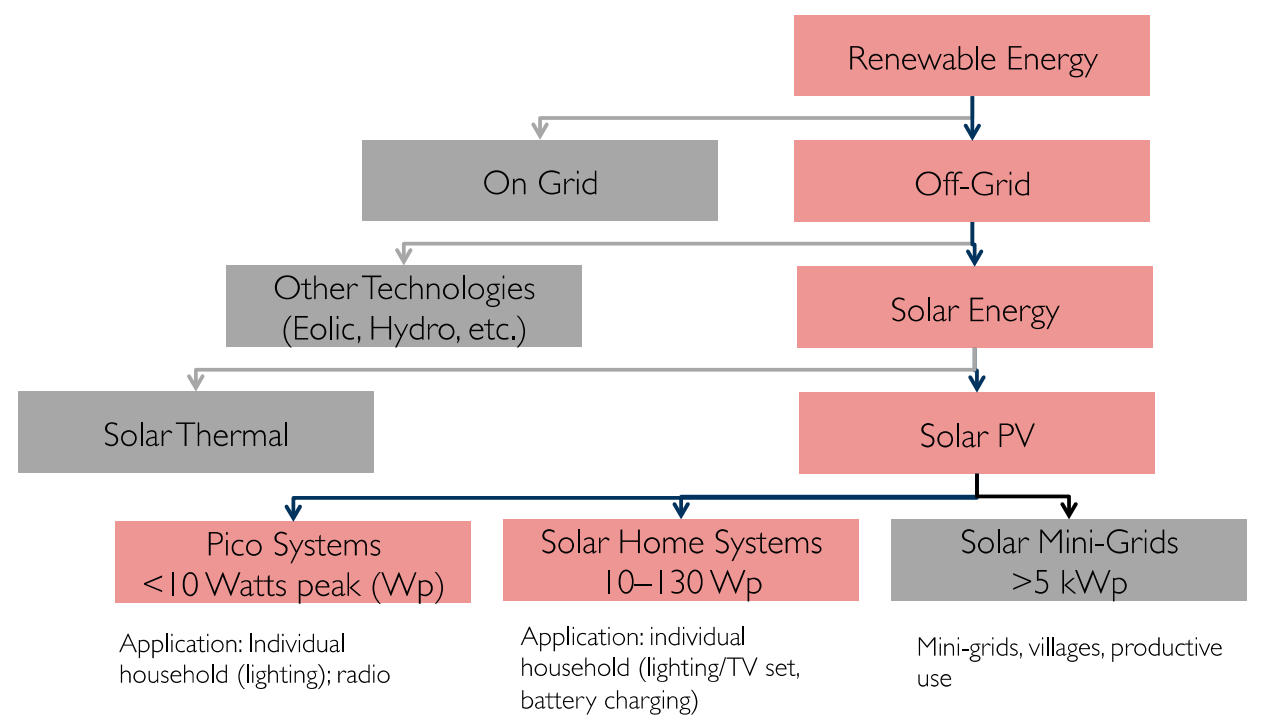

Figure 1. Types of solar PV systems. In this paper, the sustainability of off-grid PV systems is addressed.

PV systems may be used in different ways: technological solutions range from very small applications such as Solar Pico Systems (SPS) (i.e., one to 10 watts, e.g., used for lightning to replace kerosene lamps) to mid-scale solutions like Solar Home Systems (SHS); the latter usually have a capacity of a 10-130 watts peak (up to a 250 watts peak has been installed in some households) [7-9]. For SHS, more artifacts, such as several lamps, a radio and TV, can be supplied with energy; yet, in addition to the PV cells, other accessories, including batteries, an inverter (to convert DC into AC) and a charge controller (to regulate the charge from a solar panel into a deep cycle battery bank), are necessary, making the system more expensive. It has been estimated that worldwide, there are about six million SHS installed today (as compared to 1.3 million systems in 2002), although significant data gaps only allow for indicative numbers [10].

PV systems have also been installed in large-scale projects, such as hospitals or whole communities. For that purpose, hybrid solutions (including, e.g., diesel generators or eolic systems) are combined and fed into a local mini-grid, which can provide energy to a whole community [9]. Yet, mini-grids will not be considered in this paper, since prior relevant efforts have already addressed mini-grids [11,12], and their uses may differ from SPS and SHS [13]. For instance, mini-grids require a combination of diverse local generators with a very high technological complexity and are used when the dispersion within the community is low [12,14].

Barriers that constrain the deployment of off-grid PV systems for rural electrification have been described in numerous studies [15-19]. Yet, apart from entry barriers for these solutions, a high failure rate of already deployed systems (i.e., feeble sustainability) has also been detected: e.g., in Guatemala, $45 \%$ of the systems were not operational [20]; in Laos, it was 65\% [21].

In this paper, the main multidimensional drawbacks that constrain the sustainability of off-grid PV systems are highlighted. Accordingly, an exhaustive electronic literature and project review was performed. Although several relevant PV-based electrification efforts are referred to below, the review was aimed at gathering an overall picture of the rural electrification efforts in DCs, rather than addressing the success or failure of specific projects. 
As explained below, the gathered information was allocated according to a set of indicators associated with the sustainability dimensions considered in this paper: institutional, economic, environmental and socio-cultural; see, e.g., [22-24].

\section{Materials and Methods}

\subsection{Theoretical Framework}

Institutional sustainability demands for stability/durability [25-30], technical and service standards, as well as coherence between laws and regulations [24-27]. Failures in rural electrification have often been attributed to the lack of coherence in the legal frame (laws, regulations and standards) $[25,27,29]$ or the absence of proper standards [31,32]. White et al. [33] have also shown how unexpected policy changes can have negative impacts on investments and cause uncertainty. Furthermore, numerous studies have underscored the fact that sustainable institutions should have the ability to adapt to future needs of the population (e.g., [25,26,34-36]).

Sustainable institutions not only need to preserve themselves over time, but they should also be open to the society and its interests, be accountable and transparent in their decision making, while equally considering the other sustainability dimensions [24]. Therefore, decentralization and participation have often been mentioned as indicators for sustainable institutions (e.g., [23,25,28,36-39]). Wüstenhagen et al. [40] argue that a top-down approach at the central government level may inhibit the acceptance of a technology at the local level. Despite the advantages of decentralization, Rondinelli et al. [41] have pointed out the fact that decentralization may be problematic if local institutions in a decentralized administration lack the expertise, know-how and management capacity to administrate the services. Indeed, numerous studies have shown that the scarcity of expert know-how on Renewable Energies (RE) can affect the sustainability of off-grid PV systems [35,42,43].

The economic sustainability of electrification solutions requires ensuring the funding or affordability of the systems (i.e., the initial investments and the Operation and Maintenance (O\&M) over its lifetime) [24,26,29,35,38,44-47]. In the energy sector, other important indicators for the economic sustainability of electrification solutions are the cost-effectiveness $[25,26,46,48]$ and the reliability of supply (see, e.g., $[25-27,34,49,50]$ ). Moreover, since energy consumption is correlated with income, efforts on rural electrification are expected to contribute to the income of its users [25,46,51-53]. However, if energy projects aim at a higher productive outcome of rural communities, electrification programs need to be coupled with complementary infrastructure, including training and education [53].

Ensuring environmental sustainability for rural electrification requires civil society's awareness of environmental issues, as their support is needed to enforce environmental policies and regulations [54]. Environmental sustainability also requires minimizing the negative impacts of energy solutions on the environment. These impacts may concern the amount of greenhouse gases, such as $\mathrm{CO}_{2}, \mathrm{SO}_{2}$ or NO (see, e.g., $[26,35,36,46,49,50,52,54,55]$ ); a loss of biodiversity due to deforestation $[26,46,50,56]$ or local impacts, such as air quality caused by pollution in households, noise or aesthetic disturbances $[26,50,52,57]$.

Socio-cultural sustainability requires considering equity/disparity criteria between different communities. In rural electrification, decisions have to be made regarding who will have access to energy (first) and how much energy is provided to each household [35,37,46,56,58]. Furthermore, attention must be paid to the accuracy of a technology for the specific environmental/socio-cultural conditions where it will be implemented [26,59], as well as to the social acceptance, which implies a participatory and inclusive approach in which the local community is engaged to increase accountability $[40,49,60]$. It is therefore vital for ensuring socio-cultural sustainability to embrace the notion of cultural justice, which in this context refers to justice through participation and recognition [61]. The cultural justice in rural electrification depends on the ability shown to integrate the 
technology into the existing social structures [26,35,50,54]. Indeed, as argued elsewhere (e.g., [34,62]), the socio-cultural context determines to what extent a technology is adopted.

The set of indicators used in Table 1 were adapted from Feron et al. [63] to qualitatively evaluate the sustainability of the analyzed rural electrification efforts.

Table 1. Indicators for the sustainability of off-grid PV systems (adapted from Feron et al. [63]).

\begin{tabular}{cccc}
\hline Institutional & Economic & Environmental & Socio-Cultural \\
\hline $\begin{array}{c}\text { Stability (durability) and } \\
\text { long-term vision }\end{array}$ & Cost effectiveness & $\begin{array}{c}\text { Environmental } \\
\text { awareness }\end{array}$ & $\begin{array}{c}\text { Accessibility } \\
\text { (disparity, equity) }\end{array}$ \\
\hline $\begin{array}{c}\text { Regulation, standards } \\
\text { and enforcement }\end{array}$ & Reliability & Environmental impact & Social acceptance \\
\hline $\begin{array}{c}\text { Decentralization and } \\
\text { openness to participation }\end{array}$ & $\begin{array}{c}\text { Funding (initial investment; } \\
\text { operation and maintenance) }\end{array}$ & Accuracy \\
\hline Expert know-how & $\begin{array}{c}\text { Contribution to } \\
\text { the income of users }\end{array}$ & - & Cultural justice \\
\hline $\begin{array}{c}\text { Adaptability (ability to } \\
\text { meet future needs }\end{array}$ & & & \\
\hline
\end{tabular}

\subsection{Methodology}

An extensive review of recent experiences since 2000 in the off-grid PV sector in DCs has been conducted. The review included: scientific papers (63), NGO reports (32), conference/working papers (12), (PhD) theses (11), books (chapters) (5) and scientific reports (3) from governments/NGOs and publications from energy institutions, such as the International Renewable Energy Agency (IRENA) or the International Energy Agency (IEA). Project databases from the World Bank, UN and the Global Environment Facility (GEF), as well as documentation from privately led projects were also reviewed.

The keyword search compiled "sustainability"/"sustainable development" and "rural electrification" /"off-grid" / "solar energy" /"solar home systems" /"SHS" /"pico PV" / "SPS". This step intended getting an overview of sustainability issues in the analyzed projects. Only experiences from DCs were analyzed; thus, any studies on developed countries were filtered out. Based on the results from Step 1, the search was further refined in a second step by successively adding either "institutional", "economic", "ecological" or "socio-cultural" to the search terms "sustainability"/"sustainable development", such that the information could be clustered according to the sustainability dimensions considered in this paper: institutional, economic, environmental and socio-cultural.

Further analysis allowed allocating the finding to the set of indicators associated with the sustainability dimensions considered in this paper. It should be noted that, albeit that sustainability has traditionally been considered to be three-dimensional (either in the form of a pillar model, concentric circles or overlapping circles; [64]), a fourth dimension (institutional) was added to the analysis due to the high relevance of institutions for the sustainability of off-grid PV systems identified in Step 1.

The search was purposely not restricted to a geographical region (within DCs), as patterns of flaws beyond country and cultural boundaries were of interest. Therefore, the review embraces different continents and countries, aiming to identify common flaws that may affect the sustainability of off-grid PV solutions. The geographic distribution of the analyzed documentation is as follows: worldwide (42); Asia (29); Africa (28); Latin America/Caribbean (16); several countries (7); and Oceania (4).

The findings are presented below.

\section{Results}

\subsection{Institutional Sustainability}

Numerous studies have highlighted the importance of institutions for sustainable rural electrification [56,65-69]. Institutions can be understood as a framework of guidelines that set the 
rules of the game for interactions between human beings [70]; while formal institutions refer to laws and regulations that have been legally enacted by actors and that determine the political, economic and enforcement system, informal institutions can be understood as religious or moral values and traditions that have been established in a certain place, though they have not been legally enacted [71].

Institutional flaws have been found to constrain the sustainability of off-grid PV systems in DCs [28,72-75]. The scarcity of durability/stability and enforcement, weak regulations or standards, incomplete decentralization/participation and the lack of adaptability are among those institutional flaws.

\subsubsection{Durability (Stability) and Enforcement}

Prior efforts have shown that sustainable off-grid PV systems require strengthened formal institutions $[15,44,74-81]$. Strengthened formal institutional are characterized by their stability (durability) and their enforcement [82]. In DCs, these two factors tend to be low, which is problematic for the sustainability of off-grid PV systems.

Concerning stability, in Ecuador for example, disruptive changes of institutions (conveyed by frequent changes in the constitution, elimination/creation of ministries and changing regulations) have been shown to compromise the sustainability of off-grid PV systems adopted for the electrification of rural indigenous communities in the Ecuadorian Amazon basin [63]. In Ghana, the weak (instable) institutional framework has been pointed out as the main reason for the lacking dissemination of SHS [83]; although incentives on RE were announced in this country, they were later rejected by lawmakers [72]. In Nigeria, political instability was revealed to be a major challenge for off-grid systems, since the electrification programs were often abandoned after a change in the government [84]. These cases show the importance of ensuring stable formal institutions for the PV system's sustainability.

Regarding enforcement, in Pakistan for example, early burnout of bulbs and failures of solar controllers were not addressed due to the lack of enforcement of warranties [85]. In South Africa, weak control and enforcement resulted in previous agreements with providers in bids for tenders [76]. In Bangladesh, on the contrary, the government-owned financial intermediary not only set technical quality standards for SHS (e.g., establishing a testing laboratory for SHS), but also enforced them, resulting in high user satisfaction [32]. Indeed, the state-owned Infrastructure Development Company Limited (IDCOL) established a Technical Standard Committee that determines the compliance with quality standards for the SHS, and their inspectors carry out physical verifications of the installed systems to enforce their regulations and standards [86,87].

The enforcement of formal institutions strongly depends on informal institutions [88]. For instance, although prohibited by law, corruption can be broadly accepted, given that the interpretation of its actual meaning is tied to norms and attitudes [88]. Informal corruptive behavior is a substantial issue for the sustainability of rural electrification efforts in DCs. In Nigeria for example, corruption was a major reason for off-grid PV failures and ultimately led to the closure of the Rural Electrification Agency [84]. In the Philippines, the selection of contracting partners for PV system installations appeared to be based on personal preferences rather than on a bidding system for the most competent partner [89]. In Pakistan, although laws and regulations for RE had been implemented, in reality, the promised incentives for companies to invest in RE only existed on paper: the conditions were actually set via negotiations between authorities and companies [75]. In Kenya, relationships and access to high-ranking governmental officials appeared to be much more important than rules and compliance with regulations [90]. Therefore, although corruption appears to have avoided the introduction of a fee for service approach (where a company/the government is the owner and sells electricity as a service) in Kenya, that approach was shown to be successful in Zambia, where stronger institutions exists [91]. 


\subsubsection{Regulations and Standards}

Prior experiences have shown that the adoption of a regulatory frame favors the sustainability of rural electrification efforts based on off-grid PV systems [75,76,92]. The existence of a regulatory agency has also been shown to have a positive effect (e.g., [93-96]).

Flaws in the institutional framework often determine the regulatory landscape in DCs [97-99]. These institutional flaws frequently refer to an incoherent legal frame (e.g., between the constitution, laws and regulations) [100]. In Ecuador for example, inconsistencies between the constitution and the regulations have been observed: though energy was declared a basic right within the Ecuadorian Constitution, it was not anchored in the law, nor put into practice [63]. Similarly, the Chinese Renewable Energy Law showed inconsistencies and even contradictions between its different versions that were frequently changed [101]. Incoherent regulations were also a major issue for off-grid PV systems in Papua New Guinea, given the inconsistent political incentives from different government bodies [15].

Directly linked to the regulatory issues are lacking technical standards. Several studies (e.g., in South Africa, Ghana or Bangladesh) have revealed that a lack of technical standards for PV systems led to dissatisfaction caused by poor system performance and ultimately to a negative promotion of these systems $[15,18,42,85,102]$. The lack of technical standards can reduce the quality of the systems and may also inflate costs. The Alliance for Rural Electrification (an international NGO) has therefore published a list of recommended quality standards for small standalone systems, but their application needs to be assured by strengthened institutions [9].

\subsubsection{Centralization/Decentralization}

Centralized formal institutions may lead to inappropriate rural electrification solutions that are not adapted to the users' needs. In Mozambique for instance, local government agents defined household lights as a priority in their preferences, but when the project was implemented, the central government installed solar streetlights instead [28]. This lack of local participation in decision-making has been frequently observed in Latin America; Canessa et al. [103] concluded in their evaluation of the Eurosolar Program in Latin America that the low participation of communities and municipalities in the project design phase (turnkey solutions "designed from above") led to substantial adaptation issues, making at risk the sustainability of the PV kits.

Decentralization is meant to facilitate participative decision-making, thus enhancing the chances of a technology to meet the needs of the population [28,36,44,58,81,104]. Decentralized institutions may be preferred for rural electrification since local users know best what they need and who they can trust [105]. However, in some cases, decentralization based on (local) self-management is too costly because of: conflicts among users; high political costs; or a lack of expertise, know-how and management capacity of local institutions for the administration of the services $[41,73,105,106]$. Indeed, issues for off-grid systems related to decentralization often arose as qualified specialists with the required (cultural and technical) expert know-how are not available in remote areas [75,79,107-110]. For example, decentralizing the administrative resources to local authorities had been a major constraint to the PV implementation in Mexico: management tasks (including finance and control) of rural electrification were reassigned to the municipalities without creating the needed capacities [73]. This lack of local agents' capacities on planning and decision-making substantially lowered the efficiency of the systems [73].

Decentralization may also increase the risk of misalignments among institutions. If responsibilities between local and central government bodies are not agreed upon by all of the involved parties, power games between central and local agents or a lacking coordination between them can lead to unsustainable PV systems. In Nepal for instance, competition and power games between the different government agents have been the result of overlaps in their tasks [72]. In Sri Lanka, the central government decided to connect a region to the grid; this decision made the off-grid systems that were previously deployed by the local government redundant, because they were not needed any 
more [111]. These organizational issues are examples of how the sustainability of the systems can be constrained by a lack of coordination between local and national governments.

According to Machado [104], the decision for or against a decentralization/centralization ultimately depends on the particular circumstances of each country. Nevertheless, polycentricity has been proposed as an alternative solution. Polycentricity is based on different authorities with overlapping jurisdictions [105] and on sharing the power between multiples actors and mechanisms [112]. The logic behind polycentricity is tackling problems of energy at several levels, such that the advantage of local initiatives (e.g., exchange of knowledge, control measures by locals who know the area, identification with a project, etc.) can be exploited in parallel with national initiatives [113]. Empirical results of decentralized small-scale electricity projects in seven countries have already shown that polycentricity may in fact improve energy governance [114]. Still, in many DCs (e.g., China, Brazil, Thailand), top-down decision-making has been preferred over a polycentric approach [115].

\subsubsection{Expert Know-How}

Several studies have shown that the scarcity of expert know-how on RE can affect the sustainability of off-grid PV systems [35,42,43]. The lack of technicians has led to poor implementations (e.g., causing shadowing or the wrong size of cables), the use of uncertified materials and to under-sizing (due to erroneous power capacity estimations) $[75,79,107-110]$. Therefore, sustainable off-grid PV systems require generating critical expert know-how. The latter is often a challenge because of significant gaps in the educational system of DCs. Tailored PV solutions for local needs would require innovation and development from local universities, but they often do not have the capacities to generate this knowledge. For example, in Bolivian universities, it was found that poor infrastructure, low wages and missing research programs hampered innovations [80]. Pansera [81] found that the institutionalization of strategic knowledge, which is fundamental to educate experts in solar energy, is still lacking in Bolivia. In Peru, the major constraint concerning human resources has been assigned to the lack of instruction on solar energy; therefore, the country has significant deficiencies in competent technicians [116]. A prioritization of capacity building as a long-term goal is therefore critical for enhancing the sustainability of off-grid PV systems.

\subsubsection{Adaptability of Institutions}

Prior experiences have shown that the sustainability of rural electrification efforts based on off-grid PV systems can be seriously compromised by the lack of adaptability of formal institutions (i.e., the ability to meet the changing needs of the rural population) $[25,34,36,117]$. Due to the lack of adaptability, the capacity of the off-grid systems tends to be too small for income-generating activities. Indeed, PV systems are typically installed without considering the population's requirements on current and future energy demand, location, technology or the energy potential for future uses [118]. For example, in Bangladesh, less than 9\% of the households used the energy from SHS to generate income [119]. Accordingly, users tend to consider the off-grid PV systems a backup solution (with limited energy capacity), being afraid of not receiving the promised grid.

\subsubsection{Key Points}

Sustainable off-grid PV systems require strengthened formal institutions, which are characterized by their stability (durability) and their enforcement. Prior rural electrification efforts have shown that weak formal institutions hinder the compliance with rules due to peoples' expectations of sudden changes or a lack of enforcement.

The adoption of a regulatory frame and standards favors the sustainability of rural electrification efforts based on off-grid PV systems. The existence of an agency aimed at rural electrification has been shown to have a positive effect. A decentralized agency may also facilitate adaptability and 
participative decision-making, thus enhancing the chances of a technology to meet the needs of the population.

\subsection{Economic Sustainability}

\subsubsection{Cost-Effectiveness}

For an electrification solution to be sustainable, it needs to be cost-effective given that financial resources are scarce, especially in DCs $[26,46,120]$. Off-grid PV systems can be a cost-effective solution in the case of dispersed populations with low per capita energy consumptions [121,122].

However, governments often favor costly conventional energy sources over RE: indeed, in 2015, global energy post-tax subsidies on coal, petroleum, natural gas and electricity totaled US $\$ 5.3$ trillion (i.e., $6.5 \%$ of the global GDP), with the greatest share given to coal (3.9\% of global GDP) [123]. In Malaysia for instance, Petroliam Nasional Berhad (PETRONAS by its acronyms; the oil and gas state company) gave a $60 \%$ subsidy on natural gas to the utilities, such that RE had to compete with extremely low prices [124]. In Nigeria, total kerosene subsidies were higher than social programs for security, critical infrastructure, human capital development and land and food security combined [125]. These subsidies are particularly high in some DCs, including the Middle East, North Africa, Afghanistan and Pakistan, the Commonwealth of Independent States and Emerging and Developing Asia, where they amounted to 13-18 percent of the respective national GDPs [123]. In Vanuatu for instance, the local electricity utility was exempted from tax duties for diesel acquisitions, thus giving them a substantial competitive advantage over RE providers for rural electrification [79]. Contrarily, duties on PV cells and modules were found to be up to 50\% in Pakistan [75]. These policies favor unsuitable energy sources, neglecting the internalization of external costs caused by environmental damages and, in turn, blocking cost-effective solutions [126].

Not only governments exhibit problems for adopting cost-effective solutions for rural electrification. PV systems have a higher initial investment, while lower Operation and Maintenance $(\mathrm{O} \& \mathrm{M})$ costs relative to other off-grid solutions (e.g., diesel generators). Therefore, low-income households avoid buying these off-grid PV systems, although over the lifetime, they would pay off [9]. Rolland [9] explains this behavior with the unavailability of financial products (e.g., microcredits) in rural areas, as well as with the near future focus of the poor population. The lack of tailored financial products can often be attributed to the deficient know-how on alternatives for financial tools that are valid for rural off-grid PV systems. In Lesotho, for instance, neither the users nor the financial institutions were properly trained to make use of financial solutions, and no lending schemes tailored for renewable systems were offered [127]. As a result, costly (and therefore, unsustainable) solutions are oftentimes chosen.

\subsubsection{Reliability}

Ensuring the sustainability of off-grid PV systems entails making the energy supply reliable $[25,27,34,50]$. For rural areas, energy reliability demands for the availability of spare parts, as well as user know-how to understand the functionalities, use the systems appropriately and exert simple maintenance [34].

The availability of spare parts has been one of the critical success factors of the SHS in Bangladesh, where spare parts were held in offices that were at most a few kilometers away from the project area [128]. However, in the case of many other rural electrification projects, spare parts are often not available due to a distribution network focused on highly populated areas $[81,129,130]$. The scarcity of spare parts makes off-grid PV systems unreliable, thus compromising their sustainability.

Moreover, user training has been proven to enhance the reliability of the systems. In Bangladesh for instance, training programs have been undertaken by IDCOL for creating awareness not only among the installation companies, but also among the customers [88]. Nonetheless, many off-grid PV projects worldwide became unsustainable as they ignored the importance of user know-how 
(e.g., [15,31,69,79,102,107,108,111,131-133]). For example, in Uganda, Tillmans and Schweizer-Ries [107] reported a substantial knowledge drop in the chain of information (manufacturer-local supervisor and NGO-local solar company and user) towards the user. This experience has shown that an organizational structure that assures transmitting the know-how for proper handling is indispensable for the systems' reliability.

\subsubsection{Initial Investment}

The sustainability of off-grid PV systems further involves ensuring the affordability of the systems. Electrification programs aimed at rural communities are usually unprofitable in DCs (due to high dispersion, low energy demand; difficult access, etc.). For instance, Best [98] found that in Argentina, logistic costs, on the one hand, and low consumption of rural populations, on the other hand, made the rural electrification market unattractive for investors.

Moreover, numerous studies have shown that the relatively high initial investment costs make off-grid PV systems unattainable for rural households in DCs $[9,79,118,124,134,135]$, except for the rural elite [136]. In India for instance, given the unequal income distribution, SHS could only be afforded by around $10 \%$ of households [135]. Part of the problem is that rural households are mainly socially deprived and not in a strong bargaining position to negotiate conditions for the acquisition of a system [111]. Even if a loan for off-grid PV systems is provided to rural families, this does not imply that the users can meet the repayment rates. In addition to the irregular income of rural families and despite being aware of their installment rates, these families often have no clear view of their earnings [111].

Due to these conditions, the sustainability of off-grid PV systems aimed at the rural population in DCs may require policy intervention, which means allocating public funds for covering both the initial investment and the O\&M of the systems or subsidizing private investment in rural electrification. In Ecuador for example, the high rate of rural electrification can be partially explained by the existence of "Fund for Rural and Urban-marginal Electrification" (FERUM by its Spanish acronym). Since 1998 until 2008, the FERUM received resources from a 10\% tax charged to the tariff paid by on-grid commercial and industrial consumers around the country, funding initial investments associated with rural electrification efforts [63]. In Bangladesh, the state-owned IDCOL provides soft loans to so-called Partner Organizations, companies that install the PV systems and operate them afterwards; IDCOL itself receives funds from international donors, such as the World Bank, to foster private investments $[87,88]$. Bangladesh also applies indirect subsidies (soft loans and slow repayment terms) [137]. In Kenya, favorable loans to users and suppliers have also contributed to the wide diffusion of SHS [138].

\subsubsection{Operation and Maintenance}

Ensuring the sustainability of off-grid PV systems requires covering O\&M over their lifetime ([29], p. 28, and [44]). However, numerous project failures can be related to the lack of funds for covering O\&M $[7,38,81]$. For example, in the case of projects funded by private donors, several studies have found that they tend to prefer only paying for the initial costs of the PV systems, avoiding the long-term commitment associated with O\&M; (e.g., [108,111]).

Part of the problem is that the O\&M costs of the off-grid PV systems can be hardly estimated, as outlay may vary considerably depending on factors, such as the availability of trained maintenance providers, community dynamics or the possibility of training local users [122]. As a consequence, O\&M costs have been frequently underestimated. For example, Carrasco et al. [139] found that in Morocco, where more than 13,000 off-grid PV systems were installed, the user fee (a fee for service approach was used) covered only $14.9 \%$ of the global costs over the system's lifetime; this fee did not cover O\&M, which led to an unsustainable economic situation. Indeed, a fee for service approach for off-grid PV systems will unlikely succeed when the rural population in DCs can hardly afford the O\&M costs for items, such as battery replacement or maintenance devices. 
Assuring the sustainability to the off-grid PV systems may therefore involve subsidizing the electricity tariffs of poor population (such that all O\&M are covered). According to Eberhard et al. [140], widespread subsidies for electricity never reach the poor; instead, the authors registered highly regressive effects from subsidies for power provision in Sub-Saharan Africa. Therefore, an effective focalized subsidy scheme (e.g., cross-tariff scheme) that reaches the poor and assures covering the O\&M is advisable $[111,127,141]$.

\subsubsection{Contribution to User Income (Productive Use)}

Electrification not only provides greater comfort to households, but it can also contribute to a higher income of the users [46,142-144]. In fact, high potentials of productive uses have been revealed in various studies (e.g., [145-149]). For instance, Glemarec [150] resumes numerous studies, which coincide that an additional household income of around US $\$ 900$ can be obtained from productive use thanks to access to electricity. This has also been observed for off-grid PV systems: for instance, in Ghana, an additional income of US $\$ 5-\$ 12 /$ day could be attained in grocery stores thanks to solar PV lighting [151].

In fact, a great variety of applications of off-grid PV systems for productive use can be found. Fishbein et al. [147] and Board [152] name among others e-commerce of digital local culture and handicrafts, artisan, rural industry, agricultural uses (e.g., pumping water for livestock, micro-irrigation, ice production for fishermen, fish farming, and milk cooling tanks), solar water heaters and ovens, shops, cinemas, tourism, stations for battery charging, food processing, drinking water pumps, grinding and refrigeration. For instance, PV-powered water pumps for irrigation have been shown to have a significant potential. For example, in Chile, the Agency for Agrarian Development (with the support of the Ministry of Energy) replaced about 1400 pumps powered by fossil fuels by PV-powered water pumps (subsidizing 90\% of the initial investment), which allowed the farmers to irrigate with very low O\&M costs [153].

Although the PV systems are in many cases even simpler than the fossil fuel solutions [147] and despite its productive potential, a study from the World Bank [154] found that still the vast majority of rural electrification is for residential use, whereas industrial development has been very limited. For example, in Bangladesh, less than 9\% of the households used the energy from SHS to generate income [119].

The limited use for income generation can be mostly explained by a lack of user know-how and proper training on the different uses of electricity [108,119]. On this note, the provision of electricity does not automatically lead to productive uses [149], but requires complementary government programs $[108,147,155]$. Interdisciplinary projects involving cross-sectorial collaboration would be needed (for example with the ministry of education or similar institutions of the respective country), but the missing cooperation between the countries' ministries or organizations makes this collaboration difficult. The Renewable Energy Project in Rural Markets (PERMER by its Spanish acronym) in Argentina for example set up about 6000 SHS and 1449 school systems with lights [98]; yet, since the program had not been aligned with other programs (such as the telecommunications or in a productive sector, like agriculture) on a province level, its impact on poverty reduction was low [98].

Similarly, in the Eurosolar Project in Latin America (which embraced Bolivia, Ecuador, El Salvador, Guatemala, Honduras, Paraguay and Peru), the different ministries (e.g., Ministry for Health, Education, with the Energy Ministry) had to work together to build an infocenter on REs; the main objective was to set up an integral program including access to the Internet, printers, computers, phones, water purification, fridges and lightning. Thus, the program required cooperation between these ministries, but the coordination became very challenging, as each of the ministries had its own budget, organization and plans [80]. As summarized by Kapadia [156], sectorial boundaries (especially with the health and the educational sector) are extremely hard to overcome and demand for considerable knowledge transfer from experts of both (several) sectors. 


\subsubsection{Key Points}

The economic sustainability of off-grid PV systems aimed at poor rural population in DCs requires policy intervention, which means allocating public funds for directly covering both the initial investment and the O\&M of the systems or for subsidizing private investment in rural electrification.

Off-grid PV systems can also decisively promote local economic development since rural electrification has the potential to contribute to the user income. However, prior experiences have shown that productive uses of off-grid PV systems require additional government programs, offering cooperation and training. Indeed, user training has been proven to enhance the reliability of the systems, ensuring in turn their sustainability.

\subsection{Environmental Sustainability}

\subsubsection{Environmental Awareness}

Environmental sustainability demands that civil society to be aware of environmental issues, such as environmental norms and regulations [86]. Kollmuss and Agyeman [157] define environmental awareness as "knowing of the impact of human behavior on the environment" (p. 253). Education is vital for creating environmental awareness, as shown, e.g., in Brazil, where the level of education was found to be a strong predictor of the awareness on environmental issues [158]. However, especially rural and remote areas in DCs often have a weak education system. For example, Yu [159] revealed in a comparative study in China that environmental awareness was much lower in rural areas than in urban areas.

Nonetheless, education is not enough for ensuring environmental sustainability, since human behavior may also be affected by external factors (such as institutional and economic factors) [157]. These external factors demand economic and institutional policies that provide regulations and incentives (e.g., subsidies on RE), as well as an appropriate infrastructure (such as recycling bins) to foster a pro-environmental behavior [157]. Often, the lack of proper education, regulations and incentives may lead to environmental issues. For example, in Ghana and in the Ecuadorian Amazon basin, the lack of policies for ensuring recycling and proper disposal of PV modules and batteries after the end of their service life resulted in the batteries being simply buried, releasing acid substances into nearby lakes and rivers $[63,160]$.

\subsubsection{Positive Environmental Impacts}

Due to their relatively low environmental impact, PV technologies for rural electrification yield long-term benefits in terms of pollution abatement and climate change mitigation. In contrast, fossil fuels can lead to important negative co-impacts as they contribute to climate change, emitting not only Greenhouse Gases (GHG), but also producing about $1 / 4$ of Short-Lived Climate Pollutants (SLCP) like black carbon (BC) [161]. BC is not only produced in households from cooking and heating, but also from lightning; Mills [162] estimates that worldwide, approximately 500 million households consume 77 billion liters of kerosene and other liquid fuels for lightning. According to Lam et al. [162], the environmental impact is significant, as $7 \%-9 \%$ of fuel from kerosene lamps converts to almost pure BC. Indeed, 270,000 tons of BC are currently emitted by these lamps, which is roughly equivalent to the forcing that 230 million tons of $\mathrm{CO}_{2}$ exerts over 100 years after its emission [163].

\subsubsection{Negative Environmental Impacts}

Although RE including off-grid PV systems are an alternative for reducing negative environmental impacts from lightning in remote areas [120], they may also do environmental harm if not properly used. As mentioned above, one major potential source of environmental co-impacts is inappropriate battery disposal. For instance, in Guatemala, Corsair [164] found that almost all users threw their lead-acid battery from off-grid PV systems away as regular waste; in one case, the battery was even given to a child as a toy. Likewise, in Nepal, the users dropped the batteries on the ground, which led 
to damages caused by acid spoiling [165]. Analogously, in Uganda, acids diluted with lead compounds were poured outside the users' houses [166]. These cases show that even presumably clean technologies may become environmentally unsustainable in the context of a scarcity of environmental awareness and regulations, weak enforcement and lacking incentives.

However, the potential negative environmental impacts of off-grid system can be overcome if regulation are adopted and enforced. In Bangladesh for example, a battery-recycling policy was introduced in 2013 when the government forced the battery retailers to recycle batteries [167].

\subsubsection{Key Points}

Although PV technologies for rural electrification yield long-term benefits in terms of pollution abatement and climate change mitigation, the lack of environmental awareness and policies (for example on ensuring recycling and proper disposal of PV modules and batteries) may also lead to negative environmental co-impacts.

\subsection{Socio-Cultural Sustainability}

\subsubsection{Accessibility (Disparity, Equity)}

The access to energy (i.e., the accessibility) is driven by the notion of social justice, which determines the equity/disparity between different groups of people (such as gender or race). Accessibility aims at equal opportunities to receive clean and reliable energy $[37,46,56,58,168]$. Off-grid PV systems offer an alternative for greater equity, as they may provide energy access to the vulnerable population (e.g., women or indigenous people) where a grid connection would not be viable [169].

As discussed elsewhere [170], energy has been key for equity from a gender perspective and was therefore included in the UN Millennium Development Goals. Household electrification is important not only because women are the main users of residential electricity, but also because they have to carry the burden of collecting biofuels (leading to physical exhaustiveness and a significant loss of their time that could be used for productive uses); girls cannot attend school because they have to help their mothers collect biofuels; without electricity, women do not have access to information through telecommunication on modern family planning, their rights and empowerment; and women are mainly exposed to indoor air pollution [170].

Nonetheless, significant inequalities in the energy sector remain between genders, especially in DC [112]. Off-grid PV systems have been no exception: for instance, in Bangladesh, between 2005 and 2010, 2797 women from low-income households received a 15-day technological training sponsored by the U.S. government agency USAID to repair and operate SHS; it aimed to integrate women into the value chain of Grameen Shakti (a subsidiary of the Grameen Bank), the fastest growing rural-based RE company of Bangladesh, and to ultimately enhance women's employment and income situation [171]. Yet, despite a huge boom of SHS installations (more than one million) in Bangladesh, none of these women got a job as an entrepreneur in the RE sector, which was partly due to male domination in the company [171]. Furthermore, in India, Sundarban women had limited control over financial assets, which left them without any decision-making power concerning electrification projects; men paid for the solar systems and were also the owners, as electricity was considered to fit into the scope of male responsibilities [172]. In addition, it was found that when women saved time thanks to a newly-introduced technology (e.g., solar cookers), men tended to become suspicious, which was explained by the fact that men felt bypassed, as they were no longer the providers of technology [173].

Energy disparity between urban and rural areas also remains in many countries and is becoming greater instead of smaller. For instance, according to Nathan [174], the gap between urban and rural electricity consumption in India has tripled in 25 years. The situation is often aggravated due to higher electricity tariffs in rural areas; e.g., in urban parts of Cambodia, tariffs amounted to US $\$ 0.15 / \mathrm{kWh}$ as compared to US $\$ 1.00 / \mathrm{kWh}$ in rural regions [175]. 


\subsubsection{Accuracy}

Accuracy implies designing energy solutions according to the socio-cultural reality, which implies meeting the needs of the local community rather than implementing a plug and play solution (without further knowledge of the local context) [26,59]. Estimating an accurate capacity of a PV system for the rural population of DC is challenging, since standardized econometric energy models used in developed countries (which estimate the demand based on a representative consumer) are not suitable for rural areas of DC [176]. While new models suitable for DCs could be developed, the lack of input data for accurately modeling the energy demand is challenging [177]. In Cambodia for example, the unavailability of statistical data on electricity demand was a main barrier for project development in rural areas [178]. This problem has been confirmed iteratively in studies focusing on DCs, e.g., by Sarkar and Singh [77], Bhattacharyya and Timilsina [179] and Mundaca and Neij [180].

Inaccurate systems often lead to unsatisfied users and in turn unsustainable solutions. For instance, in Indonesia, users were dissatisfied with the SHS, because they expected them to run applications, such as TVs or radios, refrigerators or rice cookers, as they had been used to from diesel generators [181]. As illustrated in that study, a higher energy demand from users was not met by the inaccurate solutions installed.

Moreover, adapting the off-grid PV systems to the local needs can be challenging, as engineers and designers (typically from developed countries) do not know who their users are and how their products are used. Hence, they often fail to adapt the systems to the local conditions [7]. For example, in Ethiopia, lamps were perceived to be of low quality, although they received a high quality rating in Germany; as revealed by Müggenburg et al. [60], this was due to different quality criteria from Ethiopian users, who appreciated attributes like the cone of light, handling for multi-purpose usage, a non-glaring lamp, robustness and the duration of the light.

Difficulties are further aggravated as users may give statements about their preferences they know the project managers want to hear, first to avoid disappointed expectations and second to continue receiving donations or subsidies. For instance, in Papua New Guinea, the motivation of the users (for receiving electricity) does not necessarily concur with the ideals of a donor: although the end-users stated that they used the electricity for expanded study hours, they actually preferred to rest at nights [15]. This can be explained by the fact that, e.g., farmers in rural areas may live in a different rhythm than urban electricity users. Similarly, although electricity from off-grid PV systems may extend working hours, which is generally advocated to increase people's income (see, e.g., $[42,119,131])$, women were found to refuse electricity given the additional work burden [173].

Women's necessities are indeed often ignored in the design of the project/technology despite their substantial importance for accurate solutions as principle energy users [182-185]. In a review of projects for sustainable energy solutions based on small-scale projects that were implemented worldwide between 2007 and 2012, Terrapon-Pfaff et al. [186] revealed that almost half of the projects poorly considered gender-related issues, if at all. In the Eurosolar Project for instance, gender was not contemplated in any way in the project design [103]. One reason for this may be that in some countries it is particularly difficult to ask for women's opinions, as they need prior permission from their husbands to reason [42]. The consequences may be devastating, as, e.g., exposed by Clancy [187]: SHS did not provide sufficient energy for family meals, and cooking with solar cooking stoves did not match with the eating time of many cultures. These issues occurred because the energy systems were designed according to men's prospects, although women were the principal energy users, resulting in inaccurate solutions for the users and ultimately in the system's abandonment. Therefore, understanding rural lifestyle is needed to tailor a technology and improve the accuracy, reducing in turn rejection and disappointments [15].

\subsubsection{Social Acceptance}

Many authors consider that ensuring the sustainability of PV systems in DC's rural areas stands for socio-cultural, rather than technological challenges $[9,31,107,108,111,188]$. For an energy system to 
be sustainable, it needs to be socially accepted, which implies the active participation and engagement of the community aimed at enhancing the accountability of the project $[40,47,50,56,60,189,190]$. Off-grid PV systems can be a great opportunity to assure social acceptance; Burton and Hubacek [191] found that, compared to large-scale solutions, small-scale energy approaches may have a higher social acceptance.

Nonetheless, lack of communication concerning the applications and limitations of off-grid PV systems can lead to false expectations and negative perceptions, thus constraining their acceptance $[107,108,192,193]$. In French Guiana for instance, users complained about a lack of relationship and insufficient contact with the installing company; the negative attitude towards the company was the principal factor for rejecting the PV systems [194]. The Renewable Energy Policy Network for the 21st Century (REN21) [195] confirm that the lack of the commitment of a community leads to a detachment of actual local requirements and the deception of rural users. As argued by Campbell et al. [196], levels and types of participation need to be mapped to all interest groups of the community that are characterized as "complex, self-organizing, self-imagining, and conceptually productive" actors.

Poor participation has been found to lead to social issues. For example, according to the UN [127], the lack of involvement of the community resulted in theft of off-grid PV components in South Africa. Indeed, vandalism took place in several countries (e.g., Papua New Guinea, Tunis, China; several African countries), and systems were broken (e.g., [3,69,85,103]). In Ethiopia, users took the systems with them instead of charging them at home due to envy issues within the community [60]. This behavior is also believed to be due to the lack of mutual social control [85]. Therefore, Frame et al. [47] propose that the community should own the systems (SHS, as well as PV solutions for community facilities like schools and health centers), which implies getting organized in a committee to administrate and maintain them to generate a sense of responsibility. Still, McKay [165] compared two models of ownership to set up off-grid PV systems in Nepal and found that social issues emerged in both cases. The first model was based on a cluster solution (i.e., community ownership), which connected several houses to a battery bank that was stored in one of the houses; despite significant cost savings of this solution, it had numerous drawbacks. Not only the users complained about the free-rider problem of their neighbors (connecting more devices than initially agreed upon), but they could not even protest about it owing to the cast system prevailing in Nepal. Additionally, when the user who held the batteries in his/her house moved during seasons, the other users did not have access to it. In the case of the individual SHS (second model) by contrast, it was observed that individual owners had sold donated components, since the community as a whole was not the owner, and thus, it did not oppose any pressure [165].

A case study conducted in Mozambique [25] provides a positive example of how the participation of the local community can contribute to the social acceptance (and in turn, to the sustainability) of energy solutions: a management committee consisting of different user groups who represented the users' interest was set up for managing and enforcing the agreed terms; it assured direct collaboration with the local government, which in turn communicated with higher government officials. The committee contributed to the engagement and commitment of the users, which made it a key success factor of the project [25].

\subsubsection{Cultural Justice}

Some authors have suggested that culture should be a sustainability dimension, e.g., in terms of cultural integrity for indigenous people [19]. Culture determines the responsible conduct and motivations of a person, risk assessment, degree of political participation, value formation and environmental awareness [197]. Cultural justice for energy concerns the respect for cultural habits and values when designing an energy solution [65]. Unfortunately, the culture of small rural communities is often not considered in the execution of public policies. For example, in Ecuador, the government has been building micro-grids for semi-nomadic communities (who regarded 
nomadism as a cultural value), who were then expected to adapt their culture to this new reality [63]. Similarly, de Swart ([198], p.12) cautions about social enterprises that implement RE in indigenous communities and unconsciously impose their values and beliefs on the people. Urmee [199] therefore argues that it is indispensable to understand the community, i.e., how decisions are made, their culture, interests and habits, which allows for a more sustainable solution. Hirmer and Cruickshank [59] argue that creating value (cultural, social, emotional, functional, etc.) for the users of an off-grid system is particularly important for its sustainability.

\subsubsection{Key Points}

Off-grid PV systems offer an alternative for greater equity, as they may provide energy access to the vulnerable population (e.g., women or indigenous people) where a grid connection would not be viable.

For an energy system to be sustainable, it must be accurate (which means meeting the needs of the community respecting its particularities and culture); and it must be socially accepted (which requires the active participation and engagement of the community in the design, implementation and operation of the project).

\section{Discussion and Conclusions}

A review of rural electrification programs and projects based on off-grid PV systems (including SPS and SHS in DCs) was conducted. The gathered information was allocated according to a set of indicators associated with the sustainability dimensions considered in this paper: institutional, economic, environmental and socio-cultural. The goal of this review is to highlight the main multidimensional challenges that may constrain the sustainability of off-grid PV systems in DCs.

Prior efforts have shown that sustainable off-grid PV systems require strengthened formal institutions, which are characterized by their stability (durability) and their enforcement. In DCs, these two factors tend to be low, which is problematic for the sustainability of off-grid PV systems. The adoption of a regulatory frame (including technical standards) and the existence of a regulatory agency tend to favor the sustainability of rural electrification efforts based on off-grid PV systems. However, prior experiences have shown that the enforcement of these formal institutions strongly depends on informal institutions. For instance, informal corruptive behavior is a substantial issue for the sustainability of rural electrification efforts in DCs. The international experience suggests that ensuring the PV system's sustainability requires paying attention to forming or adopting formal institutions, as well as ensuring their enforcement.

Centralized formal institutions may lead to inappropriate rural electrification solutions that are not adapted to the users' needs. Decentralization is meant to facilitate adaptability and a participative decision-making, thus enhancing the chances of a technology to meet the needs of the population. However, decentralization may also increase the risk of weak coordination between local and national governments and the lack of expert know-how (often not available in remote areas).

The lack of expert know-how is related to significant gaps in the educational system of DCs since local universities often do not have proper capacities to generate this knowledge. The lack of technicians has led to poor implementations (e.g., causing shadowing or the wrong size of cables), the use of uncertified materials and to under-sizing (due to erroneous power capacity estimations). A prioritization of capacity building as a long-term goal is therefore critical for enhancing the sustainability of off-grid PV systems.

Not only expert know-how is required. Many off-grid PV projects worldwide became unreliable (and in turn, unsustainable) as they ignored the importance of the user know-how. An organizational structure that assures transmitting the know-how for proper handling is indispensable for the systems' sustainability.

For an electrification solution to be sustainable, it also needs to be affordable and cost effective. Although off-grid PV systems are a cost-effective electrification solution in the case of disperse 
populations with low per capita energy consumption, governments often favor costly conventional energy sources over RE. Not only governments exhibit problems for adopting cost-effective solutions for rural electrification. The unavailability of financial products (e.g., microcredits) and the higher initial investment of PV systems make off-grid PV systems unattainable for rural households in DCs and often force the poor population in rural areas to choose costly (and therefore, unsustainable) solutions.

The economic sustainability of off-grid PV systems aimed at poor rural populations in DCs may require policy intervention, which means allocating public funds for covering both the initial investment and the O\&M of the systems. Numerous project failures can be related to the lack of funds for covering O\&M or their underestimation. Therefore, assuring the sustainability of the off-grid PV systems requires an effective focalized subsidy scheme (e.g., cross-tariff scheme) for the electricity tariffs of poor population (such that all O\&M are covered).

Although electrification is expected to contribute to a higher income of the users, several cases worldwide show that the provision of electricity does not automatically lead to productive uses. Part of the problem arises from the lack of user know-how and proper training on the different uses of electricity, which demands for interdisciplinary projects involving cross-sectorial collaboration (for example, with the ministry of education or a similar institution).

Due to their relatively low environmental impact, PV technologies for rural electrification yield long-term benefits in terms of pollution abatement and climate change mitigation. However, the lack of environmental awareness and policies (for example, on ensuring recycling and proper disposal of PV modules and batteries) has led to environmental co-impacts in several DCs. These lessons shows that even presumably clean technologies may become environmentally unsustainable in the context of the scarcity of environmental awareness and regulations, weak enforcement of regulations and the lack of incentives.

Off-grid PV systems offer an alternative for greater equity as they may provide energy access to the vulnerable population (e.g., women or indigenous people) where a grid connection would not be viable. However, energy solutions should be designed accurately (i.e., according to the socio-cultural reality of the users). Inaccurate systems (unable to meet the actual energy demand) often lead to unsatisfied users and, in turn, unsustainable solutions. Several cases worldwide show that understanding the rural lifestyle is needed to tailor a technology and improving the accuracy, reducing in turn rejection and deception.

For an energy system to be sustainable, it needs to be socially accepted, which implies the active participation and engagement of the community aimed at enhancing the accountability of the project. Compared to large-scale solutions, small-scale energy approaches may have a higher social acceptance. However, a lack of communication concerning the applications and limitations of off-grid PV systems can lead to false expectations and negative perceptions, thus constraining their social acceptance. Prior experiences show that in order to avoid social issues (envy, stealing, etc.), participation needs to include all interest groups of the community.

Sustainable energy solutions should be designed respecting the cultural habits and values of local population. Unfortunately, the culture of small rural communities is often not considered in the execution of public policies in DCs. Sustainable energy solutions for small rural communities require better understanding the community, i.e., how decisions are made, their culture, interests and habits. Progress regarding social acceptance, accuracy and cultural justice is urgently needed for ensuring the socio-cultural sustainability of rural electrification efforts in DCs.

The reviewed efforts on rural electrification have shown that ensuring sustainability requires an integrated and multidimensional approach. Although the dimensions of sustainability (institutional, economic, environmental and socio-cultural) are strongly interwoven and are deeply interdependent, prior experiences have underlined the importance of paying special attention to the institutional dimension. Indeed, the absence of strengthened and sustainable formal institutions appears to be a major drawback in DCs that, by inhibiting law enforcement, compromises the environmental and socio-cultural sustainability of rural electrification efforts, particularly in rural areas. 
Acknowledgments: The support of Corporación de Fomento de la Producción (CORFO) (Preis 14BPC4-28651 and 15BP-45364) and Comisión Nacional de Investigación Científica y Tecnológica (CONICYT)-Anillo ACT1410 is gratefully acknowledged.

Conflicts of Interest: The author declares no conflict of interest.

$\begin{array}{ll}\text { Abbreviations } & \\ \text { BC } & \text { Black Carbon } \\ \mathrm{CO}_{2} & \text { Carbon dioxide } \\ \mathrm{CC} & \text { Climate Change } \\ \text { CTF } & \text { Clean Technology Fund } \\ \text { DCs } & \text { Developing Countries } \\ \text { FERUM } & \text { Fund for Rural and Urban-marginal Electrification } \\ \text { FDI } & \text { Foreign Direct Investments } \\ \text { GEF } & \text { Global Environmental Facility } \\ \text { GHG } & \text { Greenhouse Gases } \\ \text { IDCOL } & \text { Infrastructure Development Company Limited } \\ \text { IEA } & \text { International Energy Agency } \\ \text { IRENA } & \text { International Renewable Energy Agency } \\ \text { kWh } & \text { Kilo Watt hours } \\ \text { NGO } & \text { Non-Governmental Organization } \\ \text { O\&M } & \text { Operation and Management } \\ \text { PERMER } & \text { Renewable Energy Project in Rural Markets } \\ \text { PETRONAS } & \text { Petroliam Nasional Berhad } \\ \text { PV } & \text { Photovoltaic } \\ \text { RE } & \text { Renewable Energy } \\ \text { REN21 } & \text { Renewable Energy Policy Network for the 21st Century } \\ \text { SD } & \text { Sustainable Development } \\ \text { SHS } & \text { Solar Home Systems } \\ \text { SLCP } & \text { Short-Lived Climate Pollutant } \\ \text { SPS } & \text { Solar Pico Systems } \\ \text { UN } & \text { United Nations } \\ \text { UNDP } & \text { United Nations Development Programme } \\ \text { WHO } & \text { World Health Organization } \\ \text { Wp } & \text { Watts peak } \\ & \end{array}$

\section{References}

1. Kaygusuz, K. Energy for sustainable development: A case of developing countries. Renew. Sustain. Energy Rev. 2012, 16, 1116-1126. [CrossRef]

2. Kirubi, C.; Jacobson, A.; Kammen, D.M.; Mills, A. Community-based electric micro-grids can contribute to rural development: Evidence from Kenya. World Dev. 2009, 37, 1208-1221. [CrossRef]

3. International Energy Agency (IEA). Comparative Study on Rural Electrification Policies in Emerging Economies; International Energy Agency: Paris, France, 2010.

4. Assembly, U.G. Transforming Our World: The 2030 Agenda for Sustainable Development; Resolution Adopted by the General Assembly on 25 September 2015; United Nations: New York, NY, USA, 2015.

5. International Energy Agency (IEA). World Energy Outlook 2015-Methodology for Energy Access Analysis. 2015. Available online: http://www.worldenergyoutlook.org/media/weowebsite/2015/EnergyAccess_ Methodology_2015.pdf (accessed on 25 June 2016).

6. International Energy Agency (IEA). World Energy Outlook. Electricity Access Database. 2015. Available online: http://www.worldenergyoutlook.org/resources/energydevelopment/energyaccessdatabase/ (accessed on 16 December 2015).

7. Lysen, E.H. Pico Solar PV Systems for Remote Homes: A New Generation of Small PV Systems for Lighting and Communication; Photovoltaic Power Systems Programme, IEA PVPS Task; International Energy Agency: St. Ursen, Switzerland, 2013.

8. Pachauri, S.; Scott, A.; Scott, L.; Shepherd, A. Energy for All: Harnessing the Power of Energy Access for Chronic Poverty Reduction; Energy Policy Guide No. 3; The Chronic Poverty Advisory Network: London, UK, 2013.

9. Rolland, S. Rural Electrification with Renewable Energy: Technologies, Quality Standards and Business Models; Alliance for Rural Electrification: Brussells, Belgium, 2011. 
10. International Renewable Energy Agency (IRENA). Off-Grid Renewable Energy Systems: Status and Methodological Issues; Working Paper; IRENA: Abu Dhabi, UAE, 2015.

11. Deshmukh, R. Sustainable Development of Renewable Energy Mini-Grids for Energy Access: A Framework for Policy Design; The University of California: Berkeley, CA, USA, 2014.

12. Dutt, P.K.; MacGill, I. Addressing some issues relating to hybrid mini grid failures in Fiji. In Proceedings of the 2013 IEEE Global Humanitarian Technology Conference: South Asia Satellite (GHTC-SAS), Trivandrum, India, 23-24 August 2013; pp. 106-111.

13. Nygaard, I. The compatibility of rural electrification and promotion of low-carbon technologies in developing countries-the case of Solar PV for Sub-Saharan Africa. Eur. Rev. Energy Mark. 2009, 3, 125-158.

14. Palit, D.; Chaurey, A. Off-grid rural electrification experiences from South Asia: Status and best practices. Energy Sustain. Dev. 2011, 15, 266-276. [CrossRef]

15. Sovacool, B.K.; D'Agostino, A.L.; Jain Bambawale, M. The socio-technical barriers to Solar Home Systems (SHS) in Papua New Guinea: Choosing pigs, prostitutes, and poker chips over panels. Energy Policy 2011, 39, 1532-1542. [CrossRef]

16. Siegel, J.R.; Rahman, A. The Diffusion of Off-Grid Solar Photovoltaic Technology in Rural Bangladesh; Energy, Climate, and Innovation Program Report; Tufts University: Medford, MA, USA, 2011.

17. Karakaya, E.; Sriwannawit, P. Barriers to the adoption of photovoltaic systems: The state of the art. Renew. Sustain. Energy Rev. 2015, 49, 60-66. [CrossRef]

18. Van Norden, S. Investigation of the Barriers for the Diffusion of Photovoltaic Systems in Cape Town. Master's Thesis, KTH School of Industrial Engineering and Management (ITM), Stockholm, Sweden, 2015.

19. Sindhu, S.; Nehra, V.; Luthra, S. Identification and analysis of barriers in implementation of solar energy in Indian rural sector using integrated ISM and fuzzy MICMAC approach. Renew. Sustain. Energy Rev. 2016, 62, 70-88. [CrossRef]

20. Nieuwenhout, F.D.J.; van Dijk, A.; Lasschuit, P.E.; van Roekel, G.; van Dijk, V.A.P.; Hirsch, D.; Wade, H. Experience with solar home systems in developing countries: A review. Prog. Photovolt. Res. Appl. 2001, 9 , 455-474. [CrossRef]

21. International Renewable Energy Agency (IRENA). Accelerating Off-Grid Renewable Energy. Second International Off-Grid Renewable Energy Conference (IOREC 2014) Key Findings and Recommendations. 2014. Available online: http://www.irena.org/DocumentDownloads/Publications/IRENA_2nd_IOREC_ 2015.pdf (accessed on 12 October 2016).

22. Burford, G.; Hoover, E.; Velasco, I.; Janoušková, S.; Jimenez, A.; Piggot, G.; Podger, D.; Harder, M.K. Bringing the "missing pillar" into sustainable development goals: Towards intersubjective values-based indicators. Sustainability 2013, 5, 3035-3059. [CrossRef]

23. Derakhshan, F. On Sustainability in Local Energy Planning; Lund University: Lund, Sweden, 2011.

24. Pfahl, S. Institutional sustainability. Int. J. Sustain. Dev. 2005, 8, 80-96. [CrossRef]

25. Sharma, T.; Balachandra, P. Benchmarking sustainability of Indian electricity system: An indicator approach. Appl. Energy 2015, 142, 206-220. [CrossRef]

26. Wimmler, C.; Hejazi, G.; de Oliveira Fernandes, E.; Moreira, C.; Connors, S. Multi-criteria decision support methods for renewable energy systems on Islands. J. Clean Energy Technol. 2015, 3, 185-195. [CrossRef]

27. Reddy, B.S. Measuring and Evaluating Energy Security and Sustainability: A Case Study of India; Working Paper 2015-008; Indira Gandhi Institute of Development Research: Mumbai, India, 2015.

28. Lyndrup, M.; Jensen, T.Y.H.W. Illuminating the Potential for a Rural Energy Service Company-Meeting the Off-Grid Electrification Challenge in Mozambique. Master's Thesis, Roskilde University, Roskilde, Denmark, 2012.

29. Ilskog, E.; Kjellström, B. And then they lived sustainably ever after?-Assessment of rural electrification cases by means of indicators. Energy Policy 2008, 36, 2674-2684. [CrossRef]

30. Bazilian, M.; Nakhooda, S.; van de Graaf, T. Energy governance and poverty. Energy Res. Soc. Sci. 2014, 1, 217-225. [CrossRef]

31. García, V.G.; Bartolomé, M.M. Rural electrification systems based on renewable energy: The social dimensions of an innovative technology. Technol. Soc. 2010, 32, 303-311. [CrossRef] 
32. World Bank. Implementation Completion and Results Report (IDA-36790 IDA-46430 IDA-50130 TF-51301) Sustainable Development Department. 2014. Available online: http://www.thegef.org/gef/sites/thegef. org/files/gef_prj_docs/GEFProjectDocuments/MandE/EO_TEs_FY13/WorldBank_TEs_APR2013/1209_ WB_TE_ICR.pdf (accessed on 14 August 2016).

33. White, W.; Lunnan, A.; Nybakk, E.; Kulisic, B. The role of governments in renewable energy: The importance of policy consistency. Biomass Bioenergy 2013, 57, 97-105. [CrossRef]

34. Dunmade, I. Indicators of sustainability: assessing the suitability of a foreign technology for a developing economy. Technol. Soc. 2002, 24, 461-471. [CrossRef]

35. Ilskog, E. Rural Electrification Sustainability Indicators: Manual for Field Workers; Royal Institute of Technology: Stockholm, Sweden, 2008.

36. Retnanestri, M. The I3A Framework-Enhancing the Sustainability of Off-Grid Photovoltaic Energy Service Delivery in Indonesia. Ph.D. Thesis, University of New South Wales (UNSW), Sydney, Australia, 2007.

37. Ribeiro, F.; Ferreira, P.; Araújo, M. The inclusion of social aspects in power planning. Renew. Sustain. Energy Rev. 2011, 15, 4361-4369. [CrossRef]

38. Winkler, H.; Simões, A.F.; Rovere, E.L.L.; Alam, M.; Rahman, A.; Mwakasonda, S. Access and affordability of electricity in developing countries. World Dev. 2011, 39, 1037-1050. [CrossRef]

39. Holland, R.; Perera, L.; Sanchez, T.; Wilkinson, R. Decentralised rural electrification: The critical success factors. Experience of ITDG (Intermediate Technology Developmental Group). Refocus 2006, 2, $28-31$. [CrossRef]

40. Wüstenhagen, R.; Wolsink, M.; Bürer, M.J. Social acceptance of renewable energy innovation: An introduction to the concept. Energy Policy 2007, 35, 2683-2691. [CrossRef]

41. Rondinelli, D.A.; Mccullough, J.S.; Johnson, R.W. Analysing decentralization policies in developing countries: A political-economy framework. Dev. Chang. 1989, 20, 57-87. [CrossRef]

42. Bawakyillenuo, S. Rural Electrification in Ghana: Issues of Photovoltaic Energy Technology Utilization. Ph.D. Thesis, University of Hull, Kingston upon Hull, UK, 2007.

43. International Energy Agency (IEA). Technology Perspectives. Scenarios \& Strategies to 2050. Available online: https://www.iea.org/publications/freepublications/publication/etp2010.pdf (accessed on 28 March 2014).

44. Breyer, C.; Werner, C.; Rolland, S.; Adelmann, P. Off-grid photovoltaic applications in regions of low electrification: High demand, fast financial amortization and large market potential. In Proceedings of the 26th European Photovoltaic Solar Energy Conference and Exhibition, Hamburg, Germany, 5-9 September 2011.

45. Rosen, M.A. Energy sustainability: A pragmatic approach and illustrations. Sustainability 2009, 1, 55-80. [CrossRef]

46. Bhattacharyya, S.C. Energy access programmes and sustainable development: A critical review and analysis. Energy Sustain. Dev. 2012, 16, 260-271. [CrossRef]

47. Frame, D.; Tembo, K.; Dolan, M.J.; Strachan, S.M.; Ault, G.W. A community based approach for sustainable off-grid PV systems in developing countries. In Proceedings of the 2011 IEEE Power and Energy Society General Meeting, Detroit, MI, USA, 24-29 July 2011; pp. 1-7.

48. Kolshus, H.H.; Vevatne, J.; Torvanger, A.; Aunan, K. Can the Clean Development Mechanism Attain Both Cost-Effectiveness and Sustainable Development Objectives; Working Paper/CICERO-Senter for klimaforskning; Universitetet i Oslo: Oslo, Norway, 2001.

49. International Atomic Energy Agency (IAEA). Energy Indicators for Sustainable Development: Guidelines and Methodologies; IAEA: Vienna, Austria, 2005.

50. Prandecki, K. Theoretical aspects of sustainable energy. Energy Environ. Eng. 2014, 2, 83-90.

51. Pereira, M.G.; Freitas, M.A.V.; da Silva, N.F. Rural electrification and energy poverty: Empirical evidences from Brazil. Renew. Sustain. Energy Rev. 2010, 14, 1229-1240. [CrossRef]

52. Vera, I.A.; Langlois, L.M.; Rogner, H.H.; Jalal, A.I.; Toth, F.L. Indicators for sustainable energy development: An initiative by the International Atomic Energy Agency. In Natural Resources Forum; Blackwell Publishing Ltd.: Hoboken, NJ, USA, 2005; Volume 29, pp. 274-283.

53. Cook, P. Infrastructure, rural electrification and development. Energy Sustain. Dev. 2011, 15, $304-313$. [CrossRef]

54. Demirtas, O. Evaluating the best renewable energy technology for sustainable energy planning. Int. J. Energy Econ. Policy 2013, 3, 23-33. 
55. Mainali, B.; Pachauri, S.; Rao, N.D.; Silveira, S. Assessing rural energy sustainability in developing countries. Energy Sustain. Dev. 2014, 19, 15-28. [CrossRef]

56. Mainali, B. Sustainability of Rural Energy Access in Developing Countries. Ph.D. Thesis, KTH Royal Institute of Technology, Stockholm, Sweden, 2014.

57. United Nations. The Energy Challenge for Achieving the Millennium Development Goals. 2005. Available online: http://www.undp.org/content/undp/en/home/librarypage/environment-energy/ sustainable_energy/the_energy_challengeforachievingthemillenniumdevelopmentgoals.html (accessed on 1 September 2016).

58. Axelsson, R.; Angelstam, P.; Degerman, E.; Teitelbaum, S.; Andersson, K.; Elbakidze, M.; Drotz, M.K. Social and cultural sustainability: Criteria, indicators, verifier variables for measurement and maps for visualization to support planning. Ambio 2013, 42, 215-228. [CrossRef] [PubMed]

59. Hirmer, S.; Cruickshank, H. The user-value of rural electrification: An analysis and adoption of existing models and theories. Renew. Sustain. Energy Rev. 2014, 34, 145-154. [CrossRef]

60. Müggenburg, H.; Tillmans, A.; Schweizer-Ries, P.; Raabe, T.; Adelmann, P. Social acceptance of PicoPV systems as a means of rural electrification-A socio-technical case study in Ethiopia. Energy Sustain. Dev. 2012, 16, 90-97. [CrossRef]

61. Fenner, R.A.; Ainger, C.M.; Cruickshank, H.J.; Guthrie, P.M. Widening engineering horizons: Addressing the complexity of sustainable development. Proc. ICE Eng. Sustain. 2006, 159, 145-154. [CrossRef]

62. Jordan, A.; O'Riordan, T. Social Institutions and Climate Change: Applying Cultural Theory to Practice; CSERGE Working Paper GEC 97-15; Centre for Social and Economic Research on the Global Environment: London, UK, 1997; p. 56.

63. Feron, S.; Heinrichs, H.; Cordero, R.R. Are the rural electrification efforts in the Ecuadorian Amazon Sustainable? Sustainability 2016, 8, 443. [CrossRef]

64. Adams, W.M. The future of sustainability: Re-thinking environment and development in the twenty-first century. In Proceedings of the IUCN Renowned Thinkers Meeting, Zurich, Switzerland, 29-31 January 2006; Volume 29, p. 31.

65. Schillebeeckx, S.J.; Parikh, P.; Bansal, R.; George, G. An integrated framework for rural electrification: Adopting a user-centric approach to business model development. Energy Policy 2012, 48, 687-697. [CrossRef]

66. The Secretary-General's Advisory Group on Energy and Climate Change (AGECC). Energy for a Sustainable Future; The Secretary-General's Advisory Group on Energy and Climate Change: New York, NY, USA, 2010.

67. Steiner, A.; Wilde, T.; Bradbrook, A.J.; Schutyser, F. International institutional arrangements in support of renewable energy. In Renewable Energy: A Global Review of Technologies, Policies and Markets; Earthscan: London, UK, 2006; pp. 152-162.

68. Martinot, E.; Chaurey, A.; Lew, D.; Moreira, J.R.; Wamukonya, N. Renewable energy markets in developing countries. Annu. Rev. Energy Environ. 2002, 27, 309-348. [CrossRef]

69. Chaurey, A.; Kandpal, T.C. Assessment and evaluation of PV based decentralized rural electrification: An overview. Renew. Sustain. Energy Rev. 2010, 14, 2266-2278. [CrossRef]

70. North, D.C. Institutionen, Institutioneller Wandel und Wirtschaftsleistung; Mohr Siebeck: Heidelberg, Germany, 1992; Volume 76.

71. Pejovich, S. The effects of the interaction of formal and informal institutions on social stability and economic development. J. Mark. Moral. 2012, 2, 164-181.

72. Brew-Hammond, A. Terminal Evaluation of UNEP GEF Project Solar and Wind Energy Resource Assessment-SWERA; United Nations Environment Programme: Nairobi, Kenya, 2011.

73. World Bank. Mexico (CRL) Rural Electrification Project Report No. AB2919. 2007. Available online: http:/ /documents.worldbank.org/curated/en/2007/03/7450052/mexico-crl-rural-electrification-project (accessed on 7 November 2013).

74. Bhatia, M.; Banerjee, S.G.; Raghunathan, K.; Soni, R. Unleashing the Potential of Renewable Energy in India; World Bank Publications: Washington, DC, USA, 2011.

75. Mani, M. Assessing the Investment Climate for Climate Investments; Policy Research Paper 6211; World Bank: Washington, DC, USA, 2012.

76. Wlokas, H.L. A Review of the Solar Home System Concession Programme in South Africa; University of Cape Town: Cape Town, South Africa, 2011. 
77. Sarkar, A.; Singh, J. Financing energy efficiency in developing countries—Lessons learned and remaining challenges. Energy Policy 2010, 38, 5560-5571. [CrossRef]

78. World Bank. Energy Efficient Lighting Options for Afghanistan; World Bank: Washington, DC, USA, 2009.

79. Polack, A. Drivers and Barriers of Renewable Energy in the Electrification of Vanuatu. Ph.D. Thesis, Murdoch University, Perth, Australia, 2010.

80. Käppler, R.; Avila, O.; Castro, M. Evaluación de Programa EUROSOLAR; Framework Contract Request No. 2010/244306/1; European Comission: Brussels, Belgium, 2010. (In Spanish)

81. Pansera, M. Renewable energy for rural areas of Bolivia. Renew. Sustain. Energy Rev. 2012, 16, $6694-6704$. [CrossRef]

82. Levitsky, S.; Murillo, M.V. Variation in Institutional Strength. Annu. Rev. Political Sci. 2009, 12, 115-133. [CrossRef]

83. Bawakyillenuo, S. Policy and institutional failures: photovoltaic solar household system (PV/SHS) dissemination in Ghana. Energy Environ. 2009, 20, 927-947. [CrossRef]

84. Elusakin Julius, E.; Olufemi, A.O.; Chuks, D.J. Challenges of sustaining off-grid power generation in Nigeria rural communities. Afr. J. Eng. Res. 2014, 2, 51-57.

85. World Bank. Policy and Governance Framework for Off-Grid Rural Electrification with Renewable Energy Sources; World Bank: Washington, DC, USA, 2008.

86. De Soysa, I.; Jütting, J. Informal Institutions and Development-What Do We Know and What Can We Do; International Seminar; OECD Development Center: Paris, France, 2006.

87. Schwan, S. Overcoming Barriers to Rural Electrification. Master's Thesis, Aarhus University, Aarhus, Denmark, 2011.

88. World Bank. Implementation Completion and Results Report (IDA-36790 IDA-46430 IDA-50130 TF-51301); World Bank: Washington, DC, USA, 2013.

89. World Bank; Sustainable Development Department-Philippines Country Management Unit. Implementation Completion and Results Report (IBRD-72040, IBRD-76730 and TF-52188); World Bank: Washington, DC, USA, 2013.

90. Ndegwah, D.; Vanheule, L.; Kroesen, O.; Kamp, L. Knowledge Transfer, Policy, Innovation Systems and Civil Society in the Energy Market; African Technology Policy Studies Network (ATPS): Nairobi, Kenya, 2011.

91. Kovic, M. Investigating technology transfer projects and institutional development in developing countries. Manag. Environ. Qual. Int. J. 2010, 21, 761-772. [CrossRef]

92. Fevrier, C. The Caribbean Renewable Energy Development Programme (CREDP). 2011. Available online: http://insula.org/eurocaribbean/CREDP.pdf (assessed on 14 August 2013).

93. Gutiérrez, L.H. The effect of endogenous regulation on telecommunications expansion and efficiency in Latin America. J. Regul. Econ. 2003, 23, 257-286. [CrossRef]

94. Wallsten, S.J. Does Sequencing Matter: Regulation and Privatization in Telecommunications Reforms; Development Research Group, Macroeconomics and Growth; World Bank: Washington, DC, USA, 2002.

95. Navajas, F.H. Hydrocarbon policy, shocks, and the collective imagination: What went wrong in Bolivia? In The Natural Resources Trap: Private Investment without Public Commitment; MIT Press: Cambridge, MA, USA, 2010; p. 331.

96. Stern, J.; Cubbin, J. Regulatory Effectiveness: The Impact of Regulation and Regulatory Governance Arrangements on Electricity Industry Outcomes; World Bank-Free PDF; World Bank: Washington, DC, USA, 2005; Volume 3536.

97. Estache, A.; Wren-Lewis, L. Toward a theory of regulation for developing countries: Following jean-jacques laffont's lead. J. Econ. Lit. 2009, 47, 729-770. [CrossRef]

98. Best, S. Remote Access Expanding Energy Provision in Rural Argentina through Public-Private Partnerships and Renewable Energy; A Case Study of the PERMER Program; International Institute for Environment and Development: London, UK, 2011.

99. Sarraf, M.; Rismanchi, B.; Saidur, R.; Ping, H.W.; Rahim, N.A. Renewable energy policies for sustainable development in Cambodia. Renew. Sustain. Energy Rev. 2013, 22, 223-229. [CrossRef]

100. Mutimba, S.; Wanyoike, R. Towards a Coherent and Cost-Effective Policy Response to Climate Change in Kenya: Country Report; Heinrich Bðll Stiftung: Nairobi, Kenya, 2013.

101. Xinlei, L.I. Cognitive learning and policy change: Analyzing renewable energy policy evolution in China. In Proceedings of the 22nd World Congress of Political Science, Madrid, Spain, 8-12 July 2012. 
102. Rahman, M.Z. Multitude of progress and unmediated problems of solar PV in Bangladesh. Renew. Sustain. Energy Rev. 2012, 16, 466-473. [CrossRef]

103. Canessa, R.; Santome, J.M.; Buss, I.N. Evaluación ex Post del Programa Euro-Solar. Informe Final Contrato Específico No. 2013/332211. 2014. Available online: https://ec.europa.eu/europeaid/sites/devco/files/ eurosolar-informe-final_es.pdf (accessed on 3 July 2016). (In Spanish)

104. Machado, F.V. Decentralization and Accountability: The Curse of Local Underdevelopment; IDB Working Paper Series 397; Inter-American Development Bank: Washington, DC, USA, 2013.

105. Andersson, K.P.; Ostrom, E. Analyzing decentralized resource regimes from a polycentric perspective. Policy Sci. 2008, 41, 71-93. [CrossRef]

106. Medard, M. A Social Analysis of Contested Fishing Practices in Lake Victoria, Tanzania. Ph.D. Thesis, Wageningen University, Wageningen, The Netherlands, 2015.

107. Tillmans, A.; Schweizer-Ries, P. Knowledge communication regarding solar home systems in Uganda: The consumers' perspective. Energy Sustain. Dev. 2011, 15, 337-346. [CrossRef]

108. Schäfer, M.; Kebir, N.; Neumann, K. Research needs for meeting the challenge of decentralized energy supply in developing countries. Energy Sustain. Dev. 2011, 15, 324-329. [CrossRef]

109. Bello, C.; Sánchez, R.; Cossoli, P.; Vera, L.; Busso, A.; Cadena, C. Evaluación del Desempeño de Sistemas Fotovoltaicos Autónomos en Zonas Rurales de la Provincia de Corrientes, Argentina. In Proceedings of the 4th Congresso Brasileiro de Energia Solar e V Conferencia Latino-Americana da ISES, São Paulo, Brazil, 18-21 September 2012.

110. Tamir, K.; Urmee, T.; Pryor, T. Issues of small scale renewable energy systems installed in rural Soum centres in Mongolia. Energy Sustain. Dev. 2015, 27, 1-9. [CrossRef]

111. Laufer, D.; Schäfer, M. The implementation of Solar Home Systems as a poverty reduction strategy-A case study in Sri Lanka. Energy Sustain. Dev. 2011, 15, 330-336. [CrossRef]

112. Sovacool, B.K. What are we doing here? Analyzing fifteen years of energy scholarship and proposing a social science research agenda. Energy Res. Soc. Sci. 2014, 1, 1-29. [CrossRef]

113. Ostrom, E. A Polycentric Approach for Coping with Climate Change; World Bank: Washington, DC, USA, 2009.

114. Sovacool, B.K. An international comparison of four polycentric approaches to climate and energy governance. Energy Policy 2011, 39, 3832-3844. [CrossRef]

115. Koster, A.M. An Institutional Approach to Understanding Energy Transitions. Ph.D. Thesis, Arizona State University, Lake Havasu City, AZ, USA, 2013.

116. Van den Akker, J. Electrificación Rural a Base de Energía Fotovoltaica en el Perú—Proyecto PER/98/G31. Gobierno de Peru, 2008. Available online: https://www.climate-eval.org/sites/default/files/evaluations/ 513\%20Photovoltaic\%20Based\%20Rural\%20Electrification.pdf (accessed on 5 October 2013). (In Spanish)

117. Brent, A.C.; Rogers, D.E. Renewable rural electrification: Sustainability assessment of mini-hybrid off-grid technological systems in the African context. Renew. Energy 2010, 35, 257-265. [CrossRef]

118. Escobar, R.; Vilar, D.; Velo, E.; Ferrer-Martí, L.; Domenech, B. Promoting and improving renewable energy projects through local capacity development. In Modelling and Optimization of Renewable Energy Systems; In Tech: Rijeka, Croatia, 2012; pp. 146-147.

119. Harun, M. The Role of Solar Home System (SHS) in Socio-Economic Development of Rural Bangladesh. Ph.D. Thesis, BRAC University, Dhaka, Bangladesh, 2015.

120. Panwar, N.L.; Kaushik, S.C.; Kothari, S. Role of renewable energy sources in environmental protection: A review. Renew. Sustain. Energy Rev. 2011, 15, 1513-1524. [CrossRef]

121. Krithika, P.R.; Palit, D. Participatory Business models for off-grid electrification. In Rural Electrification through Decentralised Off-Grid Systems in Developing Countries; Springer: London, UK, 2013; pp. 187-225.

122. Ranaboldo, M.; Domenech, B.; Reyes, G.A.; Ferrer-Martí, L.; Moreno, R.P.; García-Villoria, A. Off-grid community electrification projects based on wind and solar energies: A case study in Nicaragua. Sol. Energy 2015, 117, 268-281. [CrossRef]

123. Coady, D.P.; Parry, I.; Sears, L.; Shang, B. How Large Are Global Energy Subsidies; International Monetary Fund Working Paper; International Monetary Fund (IMF): Washington, DC, USA, 2015.

124. Oh, T.H.; Pang, S.Y.; Chua, S.C. Energy policy and alternative energy in Malaysia: Issues and challenges for sustainable growth. Renew. Sustain. Energy Rev. 2010, 14, 1241-1252. [CrossRef]

125. Mills, E. Lifting the Darkness on the Price of Light: Assessing the Effect of Subsidies for Fuels in the Off-Grid Lighting Market in West Africa; United Nations Environmental Program: Geneva, Switzerland, 2014. 
126. Whitley, S.; van der Burg, L. Fossil Fuel Subsidy Reform in Sub-Saharan Africa: From Rhetoric to Reality; Working Paper; The New Climate Economy: Washington, DC, USA, 2015.

127. United Nations (UN). Renewable Energy-Based Rural Electrification in Lesotho. Electronic Document. 2006. Available online: http://www.undp.org.ls/energy/renewable_energy.php (accessed on 14 December 2013).

128. Urmee, T.; Harries, D. Determinants of the success and sustainability of Bangladesh's SHS program. Renew. Energy 2011, 36, 2822-2830. [CrossRef]

129. Van der Vleuten, F.; Stam, N.; van der Plas, R. Putting solar home system programmes into perspective: What lessons are relevant? Energy Policy 2007, 35, 1439-1451. [CrossRef]

130. Mondal, M.A.H.; Kamp, L.M.; Pachova, N.I. Drivers, barriers, and strategies for implementation of renewable energy technologies in rural areas in Bangladesh-An innovation system analysis. Energy Policy 2010, 38, 4626-4634. [CrossRef]

131. Das, D. Is solar electrification a sustainable solution for rural electrification? Learning from field experience. Indian J. Energy 2013, 2, 121-128.

132. Wahi, R.R.H.; Ahsan, N.U. Feasibility study of solar home system in rural areas of Bangladesh: Prospect, progress and challenges. In Proceedings of the Global Engineering, Science and Technology Conference 2012, Dhaka, Bangladesh, 28-29 December 2012.

133. Brent, A.C.; Kruger, W.J. Systems analyses and the sustainable transfer of renewable energy technologies: A focus on remote areas of Africa. Renew. Energy 2009, 34, 1774-1781. [CrossRef]

134. Kumar, A.; Mohanty, P.; Palit, D.; Chaurey, A. Approach for standardization of off-grid electrification projects. Renew. Sustain. Energy Rev. 2009, 13, 1946-1956. [CrossRef]

135. Kamalapur, G.D.; Udaykumar, R.Y. Rural electrification in India and feasibility of photovoltaic solar home systems. Int. J. Electr. Power Energy Syst. 2011, 33, 594-599. [CrossRef]

136. Karekezi, S.; Kithyoma, W. Renewable energy strategies for rural Africa: Is a PV-led renewable energy strategy the right approach for providing modern energy to the rural poor of sub-Saharan Africa? Energy Policy 2002, 30, 1071-1086. [CrossRef]

137. Rahman, M.M.; Paatero, J.V.; Poudyal, A.; Lahdelma, R. Driving and hindering factors for rural electrification in developing countries: Lessons from Bangladesh. Energy Policy 2013, 61, 840-851. [CrossRef]

138. Hansen, U.E.; Pedersen, M.B.; Nygaard, I. Review of Solar PV Market Development in East Africa; UNEP Risø Centre, Technical University of Denmark: Kongens Lyngby, Denmark, 2014.

139. Carrasco, L.M.; Narvarte, L.; Lorenzo, E. Operational costs of A 13,000 solar home systems rural electrification programme. Renew. Sustain. Energy Rev. 2013, 20, 1-7. [CrossRef]

140. Eberhard, A.; Foster, V.; Briceño-Garmendia, C.; Ouedraogo, F.; Camos, D.; Shkaratan, M. Underpowered: The State of the Power Sector in Sub-Saharan Africa; Background Paper 6; World Bank: Washington, DC, USA, 2008.

141. Moss, J.; McMann, M.; Zipprich, A.; Macer, D.R.; Nyambati, A.R.; Ngo, D.; Wolbring, G. Energy Equity and Environmental Security; Regional Unit for Social and Human Sciences in Asia and the Pacific; United Nations Educational, Scientific and Cultural Organization (UNESCO): Bangkok, Thailand, 2011.

142. Economic Consulting Associates. Correlation and Causation between Energy Development and Economic Growth; Evidence on Demand; Economic Consulting Associates: London, UK, 2014; p. 32.

143. Van Campen, B.; Guidi, D.; Best, G. Solar photovoltaics for sustainable agriculture and rural development. In Rural Development; Environment and Natural Resources Working Paper No. 2; Food and Agriculture Organization (FAO) Publication: Rome, Italy, 2000.

144. Renewable Energy Policy Network for the 21st Century (REN21). Renewables 2014-Global Status Report REN21 Secretariat; REN21: Paris, France, 2014; Available online: http://www.ren21.net/Portals/0/ documents/Resources/GSR/2014/GSR2014_KeyFindings_low\%20res.pdf (accessed on 14 January 2016).

145. Vyas, Y. Terminal Evaluation of the Renewable Energy-Based Rural Electrification Programme for Botswana. 2011. Available online: https://info.undp.org/docs/pdc/Documents/BWA/00036350_Inception\% 20Report\%20-\%20RE-Botswana\%20Terminal\%20Evaluation\%20_Final_.pdf (accessed on 5 July 2016).

146. Ahlborg, H.; Hammar, L. Drivers and Barriers to Rural Electrification in Tanzania and Mozambique-Grid Extension, Off-Grid and Renewable Energy Sources; World Renewable Energy Congress: Linköping, Sweden, 2011.

147. Fishbein, R.E.; Sanghvi, A.P.; Unit, A.E. Survey of Productive Uses of Electricity in Rural Areas; World Bank: Washington, DC, USA, 2003.

148. Finucane, J.; Bogach, S.; Garcia, L.E. Promoción de Los usos Productivos de la Electricidad en las Áreas Rurales de Perú: Experiencia y Lecciones Aprendidas; The World Bank Group: Washington, DC, USA, 2012. (In Spanish) 
149. Pool, F. Pacific Islands Greenhouse Gas Abatement through Renewable Energy Project (PIGGAREP). UNDP, SPREP, and GEF. 2010. Available online: https://erc.undp.org/evaluation/documents/download/4478 (accessed on 26 June 2016).

150. Glemarec, Y. Financing off-grid sustainable energy access for the poor. Energy Policy 2012, 47, 87-93. [CrossRef]

151. Obeng, G.Y.; Evers, H.D. Impacts of public solar PV electrification on rural micro-enterprises: The case of Ghana. Energy Sustain. Dev. 2010, 14, 223-231. [CrossRef]

152. Board, M.S. Designing Sustainable Off-Grid Rural Electrification Projects: Principles and Practices; World Bank: Washington, DC, USA, 2008.

153. Feron, S.; Heinrichs, H.; Cordero, R.R. Sustainability of rural electrification programs based on off-grid photovoltaic (PV) systems in Chile. Energy Sustain. Soc. 2016, 6, 32. [CrossRef]

154. World Bank. The Welfare Impact of Rural Electrification: A Reassessment of the Costs and Benefits; An IEG Impact Evaluation; World Bank: Washington, DC, USA, 2008.

155. Obeng, G.Y.; Evers, H.D. Solar PV Rural Electrification and Energy-Poverty: A Review and Conceptual Framework with Reference to Ghana; ZEF Working Paper Series No. 36; The Center for Development Research (ZEF): Bonn, Germany, 2009; pp. 1-18.

156. Kapadia, K. Productive Uses of Renewable Energy: A Review of Four Bank-GEF Projects; Consultant Report to World Bank; World Bank: Washington, DC, USA, 2004.

157. Kollmuss, A.; Agyeman, J. Mind the gap: Why do people act environmentally and what are the barriers to pro-environmental behavior? Environ. Educ. Res. 2002, 8, 239-260. [CrossRef]

158. Aklin, M.; Bayer, P.; Harish, S.P.; Urpelainen, J. Understanding environmental policy preferences: New evidence from Brazil. Ecol. Econ. 2013, 94, 28-36. [CrossRef]

159. Yu, X. Is environment 'a city thing' in China? Rural-urban differences in environmental attitudes. J. Environ. Psychol. 2014, 38, 39-48. [CrossRef]

160. Boateng, E. The potential socio-economic and environmental impacts of solar PV mini-grid deployment on local communities: A case study of rural island communities on the Volta Lake, Ghana. Master's Thesis, University of Jyväskylä, Jyväskylä, Finland, 2016.

161. World Health Organization (WHO). Burning Opportunity: Clean Household Energy for Health, Sustainable Development, and Wellbeing of Women and Children; WHO: Geneva, Switzerland, 2016.

162. Mills, E. The specter of fuel-based lighting. Science 2005, 308, 1263-1264. [CrossRef] [PubMed]

163. Lam, N.L.; Chen, Y.; Weyant, C.; Venkataraman, C.; Sadavarte, P.; Johnson, M.A.; Bond, T.C. Household light makes global heat: High black carbon emissions from kerosene wick lamps. Environ. Sci. Technol. 2012, 46, 13531-13538. [CrossRef] [PubMed]

164. Corsair, H.J. Causes of Success and Failure of Stand-alone Solar Electric Systems in Rural Guatemala. Ph.D. Thesis, Johns Hopkins University, Baltimore, MD, USA, 2014.

165. McKay, K.H. Socio-cultural dimensions of cluster vs. single home photovoltaic solar energy systems in Rural Nepal. Sustainability 2010, 2, 494-504. [CrossRef]

166. Sandgren, A. Batteries Used within Solar Electric Systems in Rural Uganda; Lund University: Lund, Sweden, 2001.

167. Batteiger, A. Off-Grid Electrification and Its Impacts on the Waste Management System-The Case of Bangladesh; International Renewable Energy Agency: Abu Dhabi, UAE, 2015; pp. 279-282.

168. Murphy, K. The social pillar of sustainable development: A literature review and framework for policy analysis. Sustain. Sci. Pract. Policy 2012, 8, 15-29.

169. Thiam, D.R. Renewable energy, poverty alleviation and developing nations: Evidence from Senegal. J. Energy S. Afr. 2011, 22, 23-34.

170. Cecelski, E. From the Millennium Development Goals towards a Gender-Sensitive Energy Policy Research and Practice: Empirical Evidence and Case Studies; Draft Synthesis Report to DFID KaR on Research Project 2005. Available online: https://assets.publishing.service.gov.uk/media/57a08c28e5274a31e0001030/R8346-dfid_ synthesis.pdf (accessed on 3 August 2016).

171. Hemson, D.; Peek, N. Integrating Women into Grameen Shakti's Renewable Energy Value Chain in Bangladesh: A Study of the Project and Lessons Learned; Development and Training Services (dTS) Inc.: Arlington, VA, USA, 2014; Bangladesh Institute for Development Studies: Dhaka, Bangladesh, 2014. 
172. Nielsen, K.B.; Waldrop, A. (Eds.) Women, Gender and Everyday Social Transformation in India; Anthem Press: London, UK, 2014.

173. Clancy, J.; Winther, T.; Matinga, M.; Oparaocha, S. Gender Equity in Access to and Benefits from Modern Energy and Improved Energy Technologies: World Development Report Background Paper; University of Twente: Enschede, The Netherlands, 2012.

174. Nathan, H.S.K. Solar energy for rural electricity in India: A misplaced emphasis. Econ. Political Wkly. 2014, $49,60-67$.

175. Phoumin, H. Renewable Energy Policies and the Solar Home System in Cambodia; ERIA Discussion Paper No. DP-2015-64; Economic Research Institute for ASEAN and East Asia: Jakarta Pusat, Indonesia, 2015.

176. Bhattacharyya, S.C.; Timilsina, G.R. Modelling energy demand of developing countries: Are the specific features adequately captured? Energy Policy 2010, 38, 1979-1990. [CrossRef]

177. Sathaye, J.; Lucon, O.; Rahman, A.; Christensen, J.; Denton, F.; Fujino, J.; Heath, G.; Kadner, S.; Mirza, M.; Rudnick, H.; et al. Renewable energy in the context of sustainable development. In IPCC Special Report on Renewable Energy Sources and Climate Change Mitigation; Edenhofer, O., Pichs-Madruga, R., Sokona, Y., Seyboth, K., Matschoss, P., Kadner, S., Zwickel, T., Eickemeier, P., Hansen, G., Schlömer, S., et al., Eds.; Cambridge University Press: Cambridge, UK; New York, NY, USA, 2011.

178. Javadi, F.S.; Rismanchi, B.; Sarraf, M.; Afshar, O.; Saidur, R.; Ping, H.W.; Rahim, N.A. Global policy of rural electrification. Renew. Sustain. Energy Rev. 2013, 19, 402-416. [CrossRef]

179. Bhattacharyya, S.C.; Timilsina, G.R. A review of energy system models. Int. J. Energy Sect. Manag. 2010, 4, 494-518. [CrossRef]

180. Mundaca, L.; Neij, L. Energy-Economy Models and Energy Efficiency Policy Evaluation for the Household Sector; IIIEE Reports; The International Institute for Industrial Environmental Economics: Lund, Sweden, 2009; Volume 2.

181. Mufiaty, H. Solar home systems performance in rural area in aceh case study: Deah mamplam village, aceh besar. Energy Procedia 2014, 47, 133-142. [CrossRef]

182. Terrapon-Pfaff, J.; Dienst, C.; König, J.; Ortiz, W. How effective are small-scale energy interventions in developing countries? Results from a post-evaluation on project-level. Appl. Energy 2014, 135, 809-814. [CrossRef]

183. Glemarec, Y.; Bayat-Renoux, F.; Waissbein, O. Removing barriers to women entrepreneurs' engagement in decentralized sustainable energy solutions for the poor. AIMS Energy 2016, 4, 136-172. [CrossRef]

184. Köhlin, G.; Sills, E.O.; Pattanayak, S.K.; Wilfong, C. Energy, Gender and Development: What are the Linkages? Where Is the Evidence; Policy Research Working Paper Series No. 5800; World Bank: Washington, DC, USA, 2011.

185. Khamati-Njenga, B.; Clancy, J. Concepts and Issues in Gender and Energy; University of Twente: Enschede, The Netherlands, 2003.

186. Terrapon-Pfaff, J.; Dienst, C.; Ortiz, W. The role of gender concerns in the planning of small-scale energy projects in developing countries. In Decentralized Solutions for Developing Economies; Springer International Publishing: New York, NY, USA, 2015; pp. 285-294.

187. Clancy, J. Policies, Projects and the Market Empowering Women? Some Initial Reactions to Developments in the Energy Sector; Working Paper; University of Twente: Enschede, The Netherlands, 2000.

188. Friebe, C.A.; von Flotow, P.; Täube, F.A. Exploring the link between products and services in low-income markets-Evidence from solar home systems. Energy Policy 2013, 52, 760-769. [CrossRef]

189. Belguedj, M.; Chantelot, E. The Role of Liquefied Petroleum (LP) Gas in Meeting the Goals of sustainable Development; World Bank: Washington, DC, USA, 2013.

190. Urmee, T.; Md, A. Social, cultural and political dimensions of off-grid renewable energy programs in developing countries. Renew. Energy 2016, 93, 159-167. [CrossRef]

191. Burton, J.; Hubacek, K. Is small beautiful? A multicriteria assessment of small-scale energy technology applications in local governments. Energy Policy 2007, 59, 200-205. [CrossRef]

192. Anuta, O.; Crossland, A.; Mcneil, B.; Wade, N. Energy Procedia Assessing the Impact of Society and Energy Storage on the Success of Solar Photovoltaic Systems Utilized for Healthcare in Rural Rwanda; Proceeding Paper; Durham University: Durham, UK, 2013.

193. Martinot, E.; Reiche, K. Regulatory Approaches to Rural Electrification and Renewable Energy: Case Studies from Six Developing Countries; Working Paper; World Bank: Washington, DC, USA, 2000. 
194. Linguet, L.; Hidair, I. A detailed analysis of the productivity of solar home system in an Amazonian environment. Renew. Sustain. Energy Rev. 2010, 14, 745-753. [CrossRef]

195. Renewable Energy Policy Network for the 21st Century (REN21). Renewables 2013-Global Status Report REN21 Secretariat; REN21: Paris, France, 2013; Available online: http://www.ren21.net/Portals/0/ documents/Resources/GSR/2013/GSR2013_lowres.pdf (accessed on 21 July 2015).

196. Campbell, B.; Cloke, J.; Brown, E. Communities of energy. Econ. Anthropol. 2016, 3, 133-144. [CrossRef]

197. Sen, A. How does culture matter? In Culture and Public Action; Rao, V., Walton, M., Eds.; Stanford University Press: Stanford, CA, USA, 2004; pp. 37-58.

198. De Swart, B. Indigenous Power: Renewable Electricity and Local Sustainability in Mexico and South America. Master's Thesis, University of London, London, UK, 2012.

199. Urmee, T. Social, cultural and policy issues of the application of remote area off-grid photovoltaic. In Proceedings of the 52nd Annual Conference Australian Solar Energy Society, Melbourne, Australia, 8-9 May 2014; p. 11.

(C) 2016 by the author; licensee MDPI, Basel, Switzerland. This article is an open access article distributed under the terms and conditions of the Creative Commons Attribution (CC-BY) license (http://creativecommons.org/licenses/by/4.0/). 